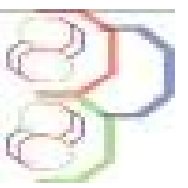

Journal of Applied Biosciences 114: 11289-11298

\title{
Physical characteristics, proximate composition and anti-nutritional factors in grains of lablab bean (Lablab purpureus) genotypes from Kenya
}

\author{
Sheila M. Kilonzi ${ }^{1,2 *}$, Anselimo O. Makokha, ${ }^{2}$ Glaston M. Kenji 2 \\ ${ }^{1}$ Department of Food Science and Nutrition, School of Agriculture and Biotechnology, Karatina University, P.O. Box \\ 1957- 10101, Karatina, Kenya \\ 2Department of Food Science and Technology, Faculty of Agriculture, Jomo Kenyatta University of Agriculture and \\ Technology, P.O. Box 62000- 00200, Nairobi, Kenya \\ ${ }^{*}$ Corresponding author Email address: skilonzi@gmail.com
}

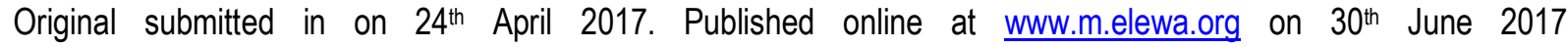
https://dx.doi.org/10.4314/jab.v114i1.2

\begin{abstract}
Objectives: The objectives of this study were to determine the physical characteristics, nutritional composition and anti-nutritional factors of grains from three lablab bean varieties with different colours and size developed by The Kenya Agricultural and Livestock Research Organisation (KALRO)

Methodology and results: The length, thickness and width were determined using Vernier callipers. Dry matter, protein, fat and ash were determined using standard association of official analytical chemists (AOAC) methods. Phytates were determined using high performance liquid chromatography (HPLC), while the tannins and trypsin inhibition were determined by UV spectrophotometry. The mean 100 seed weight was significantly different among the three varieties, and ranged from $26.1 \mathrm{~g}$ to $29.2 \mathrm{~g}$. The length, thickness and width ranged from 9.7 for KAT/DL-3 to $10.7 \mathrm{~mm}$ for KAT/DL-1, 5.2 (KAT/DL-1) to $5.6 \mathrm{~mm}$ (KAT/DL-2) and 6.8 (KAT/DL-3) to $7.4 \mathrm{~mm}$ (KAT/DL-1), respectively. The hydration and swelling coefficients of the beans ranged from 130.7 in KAT/DL-2 to 147.2 in KAT/DL-1, and 125.1 in KAT/DL-2 to 153.3 (KAT/DL-1), respectively. The mean crude protein and energy contents varied from 22.5(KAT/DL-3) to $25.4 \%$, ( KAT/DL-1) and 347.4 (KAT/DL-3) to $353.7 \mathrm{KCal} / 100 \mathrm{~g}$ in KAT/DL-1, respectively, and differed significantly $(p<0.05)$ among the varieties. There were significant differences $(p<0.05)$ in the phytic acid and tannin levels, where KAT/DL-2 recorded the highest levels of $723.6 \mathrm{mg} / 100 \mathrm{~g}$, and $0.33 \% \mathrm{CE}$, respectively.

Conclusion and application of findings: These results indicate that KAT/DL-1 has the best physical characteristics in respect to cooking and nutrition quality. This variety had the highest protein and energy content with low anti-nutritional factors, thus could offer better nutritive value in comparison to KATDL-2 and KAT/DL-3
\end{abstract}

Keywords: Lablab beans, varieties, proximate composition, physical parameters, anti-nutritional factors

\section{INTRODUCTION}

The global challenges of hunger, malnutrition, poverty are likely to become worse due to climate change, particularly in sub-Sahara Africa. This necessitates exploring the potential of underutilized grain legumes for mitigation of food and nutrition insecurity. The Lablab bean, (Lablab purpureus) also referred to as Dolichos lablab is one such legume. It belongs to a species of beans 
in the family Fabaceae that is native to Africa and was in existence in1500 BC (Maass et al., 2010). It is a drought tolerant legume, and is part of the staple foods for some communities in Africa and Asia (Kimani et al., 2012). For the low income communities, such legume grains are an important source of relatively cheap dietary proteins, in comparison to animal sources (Tharanathan \& Mahadevamma, 2003; Vohra et al., 2015). Apart from using the grain, the immature pods can be used as vegetable while the crop residue after harvest serves as manure (National Research Council, 2006). In Australia and other places it is used as a forage and feed crop (Abeke et al., 2008; Maass et al., 2010)Furthermore legume seeds have been reported to be useful in the prevention and management of common metabolic diseases such as diabetes mellitus and coronary heart diseases (Mathers, 2002; Morris, 2003; Singhal, et al., 2014). The Lablab crop has been documented to exhibit diverse agro-morphological characteristics and to be one of the most versatile legumes in the tropics (Maass et al., 2010). It is one of the most drought tolerant legumes (Amole et al., 2013), with the ability to extract soil water from a depth of two metres even in heavy-textured soils (Cook et al., 2005; Muchow, 1985), hence its adaptability in arid and semi-arid areas. Despite its importance in the food and farming systems, particularly among communities in arid and semiarid lands, the lablab bean has remained neglected and underutilized in many African countries, (National Research Council 2006). Indeed Maass et al., (2010) classified it among the lost crops of Africa. Though it has been reported to be of high nutritional value (Foyer et al., 2016; Hossain et al., 2016), it is of limited economic importance in the global market, consequently attracting minimal attention from researchers and the food industry (Foyer et al., 2016). In Kenya, it

\section{MATERIALS AND METHODS}

Samples and preparation: Three freshly harvested varieties of lablab bean (Lablab purpureus) -KAT/DL-1, KAT/DL-2 and KAT/DL-3, were obtained from Kenya Agricultural and Livestock Research Organization (KALRO), Katumani Dry land Research Station. The is mainly grown in the semi-arid areas at subsistence level hence there are no proper records regarding its production. The limited research work on the bean has mostly focused on its genetic and agronomic aspects (Karachi et al.,2003). The Kenya Agricultural and Livestock Research Organisation (KALRO) has developed and released three lablab bean varieties (Nyamongo et al., 2015). These are KAT/DL-1 (brown in colour), KAT/DL-2 (black) and KAT/DL-3 (cream). Though these varieties are different in appearance, there is no information on their nutritional, anti-nutritional factors and other physical characteristics. Other studies have shown that lablab bean varieties and accessions may differ significantly in their physical and nutritional characteristics. Apart from the nutrients, the lablab beans, as is the case with other legume grains, may also contain varying amounts of antinutritional factors such as tannins, phytic acid and trypsin inhibitors. These anti-nutrients reduce the absorption and bioavailability of nutrients in legume grains (Chavan et al., 1979; Makokha et al., 2002; Shaahu et al, 2015). The physical characteristics, including size, and hydration characteristics of the legume seeds influence consumer acceptability of these grains. They also determine the cooking and processing characteristics, of these beans (Ojo \& Adeomowaye, 2015). The physical properties may also influence the design of equipment for harvesting, transporting, cleaning, separating, packing and storing the beans (Altuntas and Demirtola, 2007). The objectives of this study were therefore to determine the physical characteristics, proximate composition and the anti-nutritional factors of the three-lablab bean varieties developed by Kenya Agricultural Livestock and Research Organization (KALRO) in Kenya with a goal of selecting the best variety for processing and nutritive value.

samples were screened to remove foreign materials and immature seeds. About 100 grams of each sample was ground into powder using a grinder, sieved to comparable particle size and packed in airtight containers for proximate composition analysis. 

factors in grains of lablab bean (Lablab purpureus) genotypes from Kenya

Seed weight: A hundred seeds were hand counted and weighed in triplicate for each variety of lablab beans and the average weight recorded as the 100 seed weight.

Length, width and thickness: The length width and thickness of 10 seeds were measured using a Vanier calliper reading to $0.01 \mathrm{~mm}$ in triplicate. The mean length, width and thickness of one seed was then determined.

Seed density: The seed density was obtained by liquid displacement. Seeds were weighed and then immersed in distilled water in a volumetric flask. The volume of the displaced water was determined. This was also the volume of the seeds. Seed density $\left(\mathrm{g} / \mathrm{cm}^{3}\right)$ was determined by dividing the weight of the seeds $(\mathrm{g})$ by the volume of the displaced water $\left(\mathrm{cm}^{3}\right)$ :

\section{weightofseeds (g) \\ wolumeof displace dwater $\left(\mathrm{cm}^{3}\right)$.}

Hydration coefficient: The hydration coefficient was determined by soaking $10 \mathrm{~g}$ of bean seeds in $50 \mathrm{ml}$ deionised water (ratio of $1: 5$ ) at $25^{\circ} \mathrm{C}$ in an incubator. After 12 hours, the lablab beans were removed from the soaking water. This was followed by free water removal by using a blotting paper. The seeds were then weighed again. The hydration coefficient was determined as:

$$
=\frac{\text { weightofbeanseedsaftersoaking }}{\text { weight of beansseedsbefores oaking }} 100
$$

(Nasar-Abbas et al, 2008)

Swelling coefficient: The volume of raw bean seeds before and after soaking in deionised water for 12 hours at room temperature was determined by measuring the volume of water displaced using a graduated cylinder. The swelling coefficient was determined by dividing the volume of the beans after soaking by the volume before soaking:

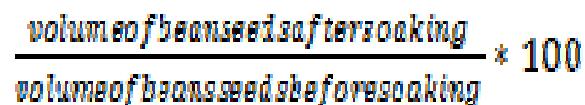

Proximate composition analysis: The proximate composition was determined according to the procedures of Association of Official Analytical Chemists (AOAC, 2005) on dry matter basis. The moisture content was determined by the dry oven method (AOAC, 2005- 925.09). Crude protein was determined by the semi Kjedahl method, multiplying the nitrogen content by the factor of 6.25 (AOAC, 2005920.152). The crude lipid content was determined using Soxhlet apparatus as described in the AOAC, 2005920.85. Total ash determination was as per the AOAC, 2005-923.3, where about $2 \mathrm{~g}$ of the sample in silica dishes was combusted in a muffle furnace at $600^{\circ} \mathrm{C}$. The carbohydrates in the samples were estimated by subtracting the sum of dry matter percentage of crude protein, crude fat, crude ash and moisture from 100 . To obtain energy values [in $\mathrm{kcal} / \mathrm{g}$ ], the Atwater specific factors (WHO/FAO, 2002)were used. The protein percent in the lablab beans was multiplied by 3.47 , fats multiplied by 8.37 and carbohydrates by 4.07 .

Determination of phytic acid: Phytic acid was determined using HPLC according to the method of Camire and Clydesdale (1982). About $0.5 \mathrm{~g}$ of the sample was extracted with $25 \mathrm{~mL}$ of $3 \% \mathrm{H}_{2} \mathrm{SO}_{4}$ in Erlenmeyer flasks for $30 \mathrm{~min}$. The solution was filtered and the filtrate heated in a boiling water bath for 5 minutes. $3 \mathrm{~mL}$ of $\mathrm{FeCl}_{3}$ solution was added to the filtrate and heated for $45 \mathrm{~min}$. The cooled solution was centrifuged for $10 \mathrm{~min}$ at $2500 \mathrm{rpm}$ and the supernatant discarded. The sample was then heated in 1:9 parts of $1.5 \mathrm{~N} \mathrm{NaOH}$ and distilled water for another $30 \mathrm{~min}$ before centrifugation. The supernatant was made to $50 \mathrm{ml}$ and micro-filtered into HPLC vials for separation on a C 18 Column of HPLC using a Refractive Index Detector.

Determination of tannins: The tannins in the lablab beans were extracted and quantified using the Vanillinhydrochloric acid method as described by Prince and Scoyoc (1978). Approximately $0.25 \mathrm{~g}$ of the samples was extracted twice with $10 \mathrm{ml}$ of $4 \% \mathrm{HCl}$ and $5 \mathrm{~mL}$ of $1 \% \mathrm{HCl}$ in methanol for $20 \mathrm{~min}$ in a shaker, respectively. The samples were then centrifuged for $10 \mathrm{~min}$ at $4500 \mathrm{rpm}$. The supernatant aliquots were transferred to $25 \mathrm{~mL}$ volumetric flasks. The aliquots volume was made up to $25 \mathrm{~mL}$. Freshly prepared vanillin- $\mathrm{HCl}$ reagent was added to $1 \mathrm{~mL}$ of the aliquots in a test tube then absorbance read at $500 \mathrm{~nm}$ after $20 \mathrm{~min}$ incubation at room temperature. The tannin content was calculated in percentage catechin equivalent (CE) Trypsin inhibitor activity: The trypsin inhibitor activity was determined according to the Kakade et al. (1974) method, with modifications by Mbithi-Mwikya et al. (2000). One gram of the sample flour was extracted with $50 \mathrm{~mL}$ of $0.01 \mathrm{~mol} / \mathrm{L} \mathrm{NaOH}$ for $1.5 \mathrm{~h}$. Portions $(0$, $0.6,1.0,1.4$ and $1.8 \mathrm{~mL}$ ) of the suspension were pipetted into duplicate sets of test tubes and adjusted to $2.0 \mathrm{~mL}$ with water. The tubes were placed in a water 
bath at $37^{\circ} \mathrm{C}$ after adding $2 \mathrm{~mL}$ of trypsin solution $(4 \mathrm{mg}$ trypsin in $200 \mathrm{~mL} 0.001 \mathrm{~mol} / \mathrm{L} \mathrm{HCl}$ ). Then $5 \mathrm{~mL}$ of BAPA solution at $37^{\circ} \mathrm{C}$ was added to each test-tube. The reaction was terminated after ten minutes by adding $1 \mathrm{~mL}$ of acetic acid $(30 \mathrm{~mL}$ acetic acid in $100 \mathrm{~mL}$ distilled water). After thorough mixing, the contents were filtered and the absorbance of the solution measured at $410 \mathrm{~nm}$ against reagent blank. Trypsin inhibitor activity (TIA) was then determined to be $=\left[\left(2.632 \times \mathrm{D} \times \mathrm{A}_{1}\right) / \mathrm{S}\right] \mathrm{mg}$ trypsin inhibition/g sample.

\section{RESULTS}

In appearance, the KAT/DL-1, KAT/DL-2 and KAT/DL-3 seeds were brown, black and cream in colour, respectively (Figure 1). The 100 seed weight was significantly $(p<0.05)$ different among the three varieties, and it ranged from $26.1 \mathrm{~g}$ in KAT/DL-1 to 29.2 $g$ in KAT/DL-2 (Table 1). The length, thickness and
Where $A_{1}=$ change in absorbance due to trypsin inhibition/mL diluted sample extract,

$D=$ dilution factor and

$\mathrm{S}=$ weight of sample $(\mathrm{g})$.

TIA is expressed as trypsin inhibitor unit per milligram of sample (TIUmg-1sample). One trypsin inhibitor unit causes an increase of 0.01 absorbance reading per 10 $\mathrm{ml}$ of the reaction mixture.

Statistical analysis: The experimental data were subjected to Analysis of Variance (ANOVA) and Duncan's multiple range test for mean separation at $P$ $\leq 0.05$ in GenStat software Version 12 .

width ranged from 9.7 to $10.7 \mathrm{~mm}, 5.2$ to $5.6 \mathrm{~mm}$ and 6.8 to $7.4 \mathrm{~mm}$, respectively. KAT/DL-1 had significantly greater length and width than the other two varieties. However, its thickness was significantly less than that of the other varieties.

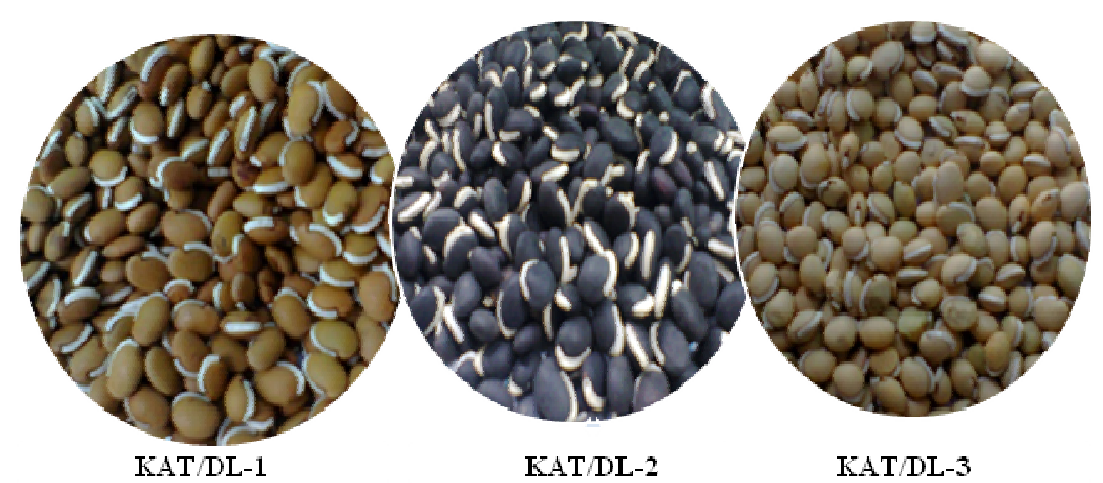

Figure 1: Three lablab bean varieties KAT/DL-1, KAT/DL-2 and KAT/DL-3

Table 1: Physical characteristics of three lablab bean varieties

\begin{tabular}{l|l|l|l|l|l}
\hline $\begin{array}{l}\text { Physical } \\
\text { parameters }\end{array}$ & Seed Colour & $\begin{array}{l}\text { 100seed } \\
\text { weight }(\mathbf{g})\end{array}$ & Length $(\mathbf{m m})$ & $\begin{array}{l}\text { Thickness } \\
(\mathbf{m m})\end{array}$ & Width $(\mathbf{m m})$ \\
\hline KAT/DL-1 & Brown & $26.1^{\mathrm{a}} \pm 0.16 \mathrm{a}$ & $10.7^{\mathrm{b}} \pm 0.98$ & $5.2^{\mathrm{a}} \pm 0.05$ & $7.4^{\mathrm{b}} \pm 0.18$ \\
\hline KAT/DL-2 & Black & $29.2^{\mathrm{c}} \pm 0.46$ & $10.3^{\mathrm{a}} \pm 0.69$ & $5.6^{\mathrm{b}} \pm 0.08$ & $7.2^{\mathrm{ab} \pm 0.14}$ \\
\hline KAT/DL-3 & Cream white & $28.3^{\mathrm{b}} \pm 0.39$ & $9.7^{\mathrm{a}} \pm 0.24$ & $5.5^{\mathrm{a}} \pm 0.25$ & $6.8^{\mathrm{a}} \pm 0.51$ \\
\hline
\end{tabular}

Means with the same letters in the same column are not significantly different $(p<0.05)$

The hydration coefficient and swelling coefficient of the three Lablab beans varieties ranged from 130.7(KAT/DL-2) to 147.2(KAT/DL-1), and 125.1 (KAT/DL2) to 153.3(KAT/DL-1), respectively (Table 2).
The coefficients of KAT/DL-1 were significantly higher than those of the other two varieties. However, there was no significant difference in the seed density among the three varieties. 


\section{Kilonzi et al., J. Appl. Biosci. 2017 Physical characteristics, proximate composition and anti-nutritional}

factors in grains of lablab bean (Lablab purpureus) genotypes from Kenya

Table 2: Hydration and swelling coefficients of three lablab bean varieties

\begin{tabular}{l|l|l|l}
\hline Parameters & Hydration coefficient & Swelling coefficient & Seed density $\left(\mathbf{g} / \mathbf{c m}^{3)}\right.$ \\
\hline KAT/DL-1 & $147.2^{\mathrm{c}} \pm 0.18$ & $153.3^{\mathrm{a}} \pm 0.21$ & $1.1^{\mathrm{a}} \pm 0.01$ \\
\hline KAT/DL-2 & $130.7^{\mathrm{a}} \pm 0.09$ & $125.1^{\mathrm{a}} \pm 0.24$ & $1.2^{\mathrm{a}} \pm 0.11$ \\
\hline KAT/DL-3 & $132.4^{\mathrm{b}} \pm 0.12$ & $133.3^{\mathrm{b}} \pm 0.12$ & $1.1^{\mathrm{a}} \pm 0.04$ \\
\hline
\end{tabular}

Means with the same letters in the same column are not significantly different $(p<0.05)$

For the proximate composition, the moisture content in the three-lablab varieties ranged from $8.1 \%$ to $9.8 \%$ (Table 3). KAT/DL-1 had significantly lower dry matter content than the other varieties. There were also significant $(p<0.05)$ differences in the protein content among the three varieties, with KAT/DL-1 having considerably higher protein content $(25.4 \%)$ than the other two varieties on dry matter basis. Similarly, there was significant difference in ash content, as KAT-DL-3 had significantly $(p<0.05)$ higher ash content $(4.4 \%)$ than the other two varieties. The carbohydrate and fat content ranged between 59.8 to $60.8 \%$ and 2.6 to $2.7 \%$, respectively. There were no significant $(p<0.05)$ differences among the three varieties in the carbohydrate and fat content. The energy content of the three varieties ranged from 347.4 to $353.7 \mathrm{Kcal} / 100 \mathrm{~g}$. KAT-DL-3 had significantly $(p<0.05)$ lower energy content than the other two varieties.

Table 3: Proximate composition of three lablab bean varieties (\%)

\begin{tabular}{l|l|l|l|l|l|l}
\hline Variety & Moisture & Crude Protein & Ash & Fats & CHO & Energy kcal/100g \\
\hline KAT/DL-1 & $8.3^{\mathrm{a}} \pm 0.1$ & $25.4^{\mathrm{a}} \pm 0.5$ & $4.0^{\mathrm{a}} \pm 0.1$ & $2.6^{\mathrm{a}} \pm 0.1$ & $59.8^{\mathrm{a}} \pm 0.3$ & $353.0^{\mathrm{b}} \pm 0.6$ \\
\hline KAT/DL-2 & $8.1^{\mathrm{a}} \pm 0.1$ & $24.4^{\mathrm{b}} \pm 0.2$ & $4.1^{\mathrm{ab}} \pm 0.2$ & $2.6^{\mathrm{a}} \pm 0.1$ & $60.8^{\mathrm{a}} \pm 0.2$ & $353.7^{\mathrm{b}} \pm 0.6$ \\
\hline KAT/DL-3 & $9.8^{\mathrm{b}} \pm 0.2$ & $22.5^{\mathrm{a}} \pm 0.5$ & $4.4^{\mathrm{b}} \pm 0.1$ & $2.7^{\mathrm{a}} \pm 0.04$ & $60.8^{\mathrm{a}} \pm 0.6$ & $347.4^{\mathrm{a}} \pm 0.5$ \\
\hline
\end{tabular}

The means in the same column with different letters are significantly different $(p<0.05)$.

Composition of protein, ash, fat and $\mathrm{CHO}$ is on dry matter basis.

For the anti-nutritional factors, there was significant $(p<0.05)$ difference in the phytic acid levels in the samples, which ranged from 533.4 in KAT/DL-3to 723.6 $\mathrm{mg} / 100 \mathrm{~g}$ in KAT/DL-2as indicated in Error! Reference source not found., The tannin levels also varied significantly $(p<0.05)$ among the samples with a range of $0.23 \%$ catechin equivalent in KAT/DL-3 to $0.33 \%$ CE in KAT/DL-2. There was no significant difference in the Trypsin inhibitor activity for all the three samples (11.5 in KAT/DL-1 to $13.1 \mathrm{mg}^{-1}$ sample KAT/DL-2).

Table 4:Anti-nutrient content in lablab beans

\begin{tabular}{|c|c|c|c|}
\hline Lablab variety & Phytic acid mg_100g & Trypsin inhibitor (TIUmg-1) & Tannins (\%CE) \\
\hline KAT/DL-1 & $687.8^{\mathrm{b}} \pm 5.46$ & $11.5 \mathrm{a} \pm 0.08$ & $0.266^{b} \pm 0.73$ \\
\hline KAT/DL-2 & $723.6^{c} \pm 7.01$ & $13.1^{\mathrm{a}} \pm 0.09$ & $0.330^{c} \pm 0.82$ \\
\hline KAT/DL-3 & $533.4^{\mathrm{a}} \pm 1.65$ & $12.5^{\mathrm{a}} \pm 0.10$ & $0.233^{a} \pm 0.49$ \\
\hline
\end{tabular}

TIU -Trypsin inhibitory unit, CE - Catechin equivalents, Values with similar letters in the same column are not significantly different $(p<0.05)$

\section{DISCUSSION}

The seeds from the three-lablab varieties were significantly different in weight, length, thickness and width. The mean and range of the seed width and length were similar to those reported in other studies (Deka \& Sarkar, 1990; Subagio, 2006). However, the mean seed thickness was observed in this study was higher than that reported by Subagio (2006) at $4.0 \mathrm{~mm}$. The KAT/DL-1 variety had the least seed weight (26.1 $\mathrm{g} / 100$ grains) among the three bean varieties, but it also had the highest length (10.7), width (7.4), swelling coefficient (153.3) and hydration coefficient (147.2). On the other hand, the black KAT/DL-2 had the highest seed weight (29.2 g/ 100 grains) and true density (1.2) but the least hydration and swelling coefficient. Mortuza observed higher seed density, hydration and swelling coefficient of lablab seeds in Bangladesh. The swelling and hydration coefficients were also significantly different among the varieties. Since hydration process aids softening and starch gelatinization, this implies that lablab variety KAT/DL-1 would have better cooking 
characteristics compared to the other two varieties. There is also the potential to select such varieties for their good cooking characteristics. However, the hydration and swelling coefficients observed in this study were lower compared to those obtained by Mortuza and Tzen (2009). The moisture content was similar to results obtained by Kamatchi et al. (2010) for lablab beans but low compared to that of various common bean varieties (12-14\%) obtained by Barros and Prudencio (2016). However, the moisture content is mainly dependent on drying and storage conditions, but not due to variety. It can also be used to predict the shelf life of the seeds. The total ash content in the three varieties was between 4.0 and $4.4 \%$. These values are in agreement with those reported in other studies(Deka \& Sarkar, 1990; Kamatchi et al., 2010; Barros \& Prudencio, 2016). However, they are higher in comparison to those observed by Hossain et al., (2016). The ash content is an indicator of the mineral content in the beans. The amount of lipids in the three samples was low (2.6\%), and in agreement with other observations for lablab beans ( Deka \& Sarkar, 1990; Chau et al.,1998; Mortuza \&Tzen, 2009; Shaahu et al, 2015), and other commonly consumed legume grains (Sridhar \& Seena, 2006; Oluwole \& Olayinka, 2011;Barros \& Prudencio, 2016; Marimuthu, et al., 2016). Significant difference in the protein content was also observed among the three varieties, where KAT/DL-1 had significantly higher protein than the other two varieties. The mean protein content was similar to what has been reported in other studies elsewhere (Chau et al., 1998; Myrene, 2013; Osman, 2007). A black variety of lablab beans analysed by Hossain et al., (2016) in Bangladesh also had similar protein content to that obtained in this study. However, other studies reported higher protein content in the lablab beans than the mean protein range observed in this study. These include Mortuza \& Tzen (2009) and Deka \& Sarkar (1990) who reported protein content of $29 \%$ in lablab bean cultivars grown in Bangladesh and Assam Agricultural University. On the other hand, (Kalpanadevi \& Mohan, 2013b) reported lower protein content of $20 \%$ in brown lablab beans grown in Tamil Nadu, India. Where the lablab beans are the main source of protein in the diet, there is therefore good potential to select and promote the production and utilization of high protein lablab varieties. This applies to many communities in developing countries who cannot easily afford animal sources of dietary protein. The relatively high carbohydrates content and energy values of the lablab seeds observed in this study are similar to those observed in other studies (Asif et al., 2013; Nakitto et al, 2015; Nazni \& Devi, 2016). They are also within the range of the other most commonly consumed legume grains (Sánchez-Chino et al., 2015). Apart from the content, the carbohydrate quality is also reported to have a low glycaemic index, as observed by Reddy et al. (2013), who reported that lablab bean seeds can be used as therapeutic diets for diabetes. This is attributed to their low post prandial glucose response and slow starch digestibility (Hedges \& Lister, 2008). . There was significant difference in the phytic acid levels among the varieties. The phytic acid content obtained in this study was similar to the levels of $800 \mathrm{mg} / 100 \mathrm{~g}$ reported by Ashok et al., (2016). On the other hand, Deka \& Sarkar (1990) and Wang et al. (2010) found relatively higher levels $(1300 \mathrm{mg} / 100 \mathrm{~g})$ of phytic acid in lablab bean varieties obtained from Assam Agricultural University, India. Yet in another study, lablab seeds from the National Seed Project-Bengaluru, India had lower levels (501 mg/100 g) of phytic acid relative to results obtained in this study (Myrna, 2013). Studies on other legume grains have indicated that phytic acid in those grains may occur in even higher amounts than what is found in lablab beans (Vijayakumari, 1997; Kakati et al., 2010; Thapliyal et al., 2014). There was also significant difference in the tannin levels among the three varieties. The black variety (KAT/DL-2) had the highest amounts $(0.33 \% \mathrm{CE})$ while variety KAT/DL-3 had lower level. These results are in agreement with those obtained by Kamatchi et al. (2010) who observed that tannin content may vary significantly among varieties as was the case for five lablab beans sourced from Tamil Nadu Agricultural University- India. However, the tannin levels in this study are relatively higher than those reported by Kalpanadevi \& Mohan (2013a), which ranged between 0.17-0.19\% CE. Nakitto et al.(2015) in their study conducted on common beans, Phaseolus vulgaris, reported even higher levels of tannins (931 $\mathrm{mg} / 100 \mathrm{~g}$ ) while Luo and Xie (2013) reported $6.45 \mathrm{mg}^{-9}$ on Viciafaba beans. The results showed no significant differences in the trypsin inhibitory activity across all the bean varieties studied..Ramakrishna et al. (2006)and Kalpanadevi \& Mohan (2013) reported similar levels of trypsin inhibitory activity in lablab samples obtained from Andhra Pradesh, India. On the other hand Shaahuet al., (2015)reported higher levels $(29 \mathrm{mg}$ 1).Studies on other legumes have achieved varying quantities of trypsin inhibitory activity. Pious \& Veerabahu, (2013) obtained up to 46 TIU $\mathrm{mg}^{-1}$ in Mucuna legume while Padmashree et al. (2016) attained 17 Trypsin inhibitory unit mg-1 in Phaseolus 
aureus. It has been observed that anti-nutritional factors' content in legume grains may differ as a result of species, cultivars, climatic conditions, soils, locations, seasons and seed germination(Sridhar \& Seena, 2006). The importance attached to these anti-nutritional factors is their ability to reduce absorption and bioavailability of nutrients in the human body (Ashok et al, 2016; Nwafor et al, 2017). However, different processing methods

\section{CONCLUSION}

Based on the results obtained, it can be concluded that KAT/DL-1 had the best physical characteristics desirable for easy cooking. The same variety also had the highest protein and energy levels important for selection of varieties with best nutritive values. Interestingly, KAT/DL-1 also had the least antinutritional levels. This variety therefore presents the

\section{ACKNOWLEDGEMENT}

The authors acknowledge the Kenya Agricultural Livestock and Research Organisation (KALRO), Katumani Dry land Research Station through Dr.Kamau who provided the research samples. This research

\section{REFERENCES}

Abeke, F. O., Ogundipe, S. O., Sekoni, A. A., Adeyinka, I. A., Oni, O. O., Abeke, A., \& Dafwang, I. I. (2008). Effect of Dietary Levels of Cooked Lablab purpureus Beans on the Performance of Broiler Chickens. American Journal of Food Technology.'https://doi.org/10.3923/ajft.2008.4 2.49

Abou-Arab, A., \& Abu-Salem, F. (2010). Nutritional quality of Jatropha curcas seeds and effect of some physical and chemical treatments on their anti-nutritional factors. African Journal of Food Science, 4(3), 93-103. Retrieved from http://eprints.icrisat.ac.in/395/

Altuntas, E. \& Demirtola, H. (2007). Effect of moisture content on physical properties of some grain legume seeds. New Zealand Journal of Crop and Horticultural Science, 35(4), 423-433. https://doi.org/10.1080/01140670709510210

Amole, T. A., Oduguwa, B. O., Shittu, O., Famakinde, A., Okwelum, N., Ojo, V. O. A., Adebiyi, A. O. (2013). Herbage yield and quality of Lablab Purpureus during the late dry season in Western Nigeria, 2013(1), 22-30.

Ashok, K., Aditya, L., \& Semwal, A. D. (2016). Effect of Microwave Drying on Nutritional and Antinutritional Factors of Dolichos Lablab such as soaking, germination and fermentation have shown significant reduction of these anti-nutrients making the beans safe for human consumption as indicated in different studies ( Mcgrath et al., 1982; Dahiya \& Kapoor, 1992; Makokha et al, 2002; Soetan \& Oyewole, 2009; Abou-Arab \& Abu-Salem, 2010; Fernandes et al., 2010; Doss et al, 2011; Okoth et al, 2011).

best option among the three varieties when selecting a lablab bean variety to shorten the time of cooking and meet the nutritional and energy requirements. Based on the different physical and nutritional characteristics, there is potential to select for lablab varieties with good cooking and nutritional characteristics among the varieties grown in Kenya.

work has been funded by Germany Academic Exchange service (DAAD), Regional Universities Forum for Capacity Building in Agriculture (RUFORUM) and International Foundation of Science (IFS).

Beans. International Journal of Science, Engineering and Technology, 4(5), 711-715.

Asif, M., Rooney, L. W., Ali, R., \& Riaz, M. N. (2013). Application and Opportunities of Pulses in Food System: A Review, Critical Reviews in Food Science and Nutrition, 53(11), 11681179. https://doi.org/10.1080/10408398.2011. 574804

Association of Official Analytical Chemists-AOAC. (2005). Official methods of analysis of the association of analytical chemists (18th ed.). AOAC.

Barros, M. De, \& Prudencio, S. H. (2016). Physical and chemical characteristics of common bean varieties. Semina: Ciências Agrárias, 37(2), 751. https://doi.org/10.5433/1679-0359. 2016 v37n2p751

Camire, A. ., \& Clydesdale, F. (1982). Analysis of Phytic acid in Foods by HPLC. Food Science, 47, 575-578.

Chau, C. F., Cheung, P. C. K., \& Wong, Y. S. (1998). Chemical composition of three underutilized legume seeds grown in China. Food Chemistry, 61(4), 505-509. https://doi.org/10.1016/S0308-8146 9700094-0 
Cook, B., Pengelly, B., Brown, S., Donnelly, J., Eagles, D., Rainer, F. A., Schultze-Kraft, R. (2005). Tropical Forages: an interactive selection tool. Web Tool. CSIRO, DPI\&F (QId), CIAT and ILRI, Brisbane, Australia.

Deka, R. ., \& Sarkar, C. (1990). Nutrient Composition and Antinutritionai Factors of Dolichos lablab L. Seeds. Food Chemistry, 38, 239-246.

Doss, A., Pugalenthi, M., Vadivel, V. G., Subhashini, G., \& Subash, A. R. (2011). Effects of processing technique on the nutritional composition and antinutrients content of under - utilized food legume. Food Chemistry, 18(3), 965-970.

Fernandes, A. C., Nishida, W., \& Da Costa Proença, R. P. (2010). Influence of soaking on the nutritional quality of common beans (Phaseolus vulgaris L.) cooked with or without the soaking water: A review. International Journal of Food Science and Technology, 45(11), 2209-2218. https://doi.org/10.1111/ j.1365-2621.2010.02395.x

Foyer, C. H., Lam, H., Nguyen, H. T., Siddique, K. H. M., Varshney, R. K., Colmer, T. D., Shi, K. (2016). Neglecting legumes has compromised human health and sustainable food production. Nature Plants, 2, Article 16112. https://doi.org/10.1038/nplants.2016.112

Hedges, L. J., \& Lister, C. E. (2008). Nutritional attributes of Indian vegetables: Plant \& Food Research Confidential Report No.2291.

Hossain, S., Ahmed, R., Bhowmick, S., Mamun, A. Al, \& Hashimoto, M. (2016). Proximate composition and fatty acid analysis of Lablab purpureus (L.) legume seed: implicates to both protein and essential fatty acid supplementation. SpringerPlus, 5(1899), 1-10. https://doi.org/10.1186/s40064-016-3587-1

Kakade, M., Rackis, J., McGhee, J., \& Puski, G. (1974). Determination of trypsin inhibitor activity of soy products: a collaborative analysis of an improved procedure. Cereal Chem, 51, 376382. Retrieved from http://naldc.nal.usda.gov/ naldc/catalog.xhtml?id=31302

Kakati, P., Deka, S., Kotoki, D., \& Saikia, S. (2010). Effect of traditional methods of processing on the nutrient contents and some antinutritional factors in newly developed cultivars of green gram [Vigna radiata (L.). International Food Research 17, 377-384. Retrieved from http://ifrj.upm.edu.my/17 (02) 2010/IFRJ-2010377-384_Deka_India\%5B1\%5D.pdf

Kalpanadevi, V., \& Mohan, V. R. (2013a). Effect of processing on antinutrients and in vitro protein digestibility of the underutilized legume, Vigna unguiculata (L.) Walp subsp . unguiculata. LWT - Food Science and Technology, 51(2), 455-461. https://doi.org/10.1016/j.Iwt.2012 .09 .030

Kalpanadevi, V., \& Mohan, V. R. (2013b). Nutritional and anti nutritional assessment of underutilized legume $D$. Lablab var . vulgaris L. Bangladesh Journal of Scientific and Industrial Research, 48(2), 119-130.

Kamatchi, K. B., Tresina, S. P., Mohan, V. R., \& Vadivel, V. (2010). Nutrient and Chemical Evaluation of Raw Seeds of Five Varieties of Lablab purpureus ( L .) Sweet. Advances in Bioresearch, 1(June), 44-53.

Karachi, M. (1997). Growth and nutritive value of Lablab purpureus accessions in semi-arid Kenya. Tropical Grasslands, 31, 214-218.

Kimani, E. N., Wachira, F. N., \& Kinyua, M. G. (2012). Molecular Diversity of Kenyan Lablab Bean ( Lablab purpureus ( L .) Sweet ) Accessions Using Amplified Fragment Length Polymorphism Markers. American Journal of Plant Sciences, (3), 313-321.

Luo, Y.-W. W., \& Xie, W.-H. H. (2013). Effect of different processing methods on certain antinutritional factors and protein digestibility in green and white faba bean (Vicia faba L.). Cyta-Journal of Food, 11(1), 43-49. https://doi.org/10.1080/19476337.2012.68170 5

Maass, B. L., Knox, M. R., Venkatesha, S. C., Angessa, T. T., Ramme, S., \& Pengelly, B. C. (2010). Lablab purpureus-A Crop Lost for Africa? Tropical Plant Biology, 3(3), 123-135. https://doi.org/10.1007/s12042-010-9046-1

Makokha, A. ., Oniang'o, R. ., Njoroge, S. ., \& Kamar, O. K. (2002). Effect of traditional fermentation and malting on phytic acid and mineral availability from sorghum (Sorghum bicolor) and finger millet (Eleusine coracana) grain varieties grown in Kenya. Food and Nutrition Bulletin. United Nations University, 23(3).

Marimuthu, M., Sundaram, U., \& Thirukannan, S. (2016). Comparative study on proximate and phytochemical analysis of processed two different germplasm of Mucuna Pruriens 
(Velvet beans), 3(5), 229-233. https://doi.org/ 10.13040/IJPSR.0975-8232.IJP.3(5).229-233

Mathers, J. C. (2002). Pulses and carcinogenesis: potential for the prevention of colon, breast and other cancers. British Journal of Nutrition, 88(S3), 273. https://doi.org/10.1079/BJN 2002717

Mbithi-Mwikya, S., Van Camp, J., Yiru, Y., \& Huyghebaert, A. (2000). Nutrient and Antinutrient Changes in Finger Millet (Eleusine coracan) During Sprouting. LWT - Food Science and Technology, 33(1), 9-14. https://doi.org/10.1006/fstl.1999.0605

Morris, B. (2003). Bio-Functional Legumes with Nutraceutical, Pharmaceutical, and Industrial Uses. BioOne, 57(2), 254-261. https://doi.org/ 10.1663/0013-0001

Mortuza, M. G., \& Tzen, J. T. (2009). Physicochemical and functional properties of ten cultivars of seem (Lablab purpureus L.), an underexploited bean in Bangladesh. Journal of the Science of Food and Agriculture, 89(8), 1277-1283. https://doi.org/10.1002/jsfa.3583

Muchow, R. C. (1985). Phenology, seed yield and water use of grain legumes grown under different soil water regimes in a semi-arid tropical environment. Field Crops Research, 11, 8197. https://doi.org/10.1016/0378-4290(85)900 93-0

Mureithi, J. G., Gachene, C. K. ., \& Ojiem, J. (2003). The role of green manure legumes in smallholder farming systems in Kenya: the legume research network project. Tropical and Subtropical Agroecosystems, (1),:57-70.

Myrene, R. D. (2013). Effect of traditional processing methods on nutritional quality of fied bean, 4(3), 29-33.

Nakitto, A. M., Muyonga, J. H., \& Nakimbugwe, D. (2015). Effects of combined traditional processing methods on the nutritional quality of beans. Food Science \& Nutrition, 3(3), 233241. https://doi.org/10.1002/fsn3.209

Nasar-Abbas, S. M., Plummer, J. A., Siddique, K. ., White, P., Harris, D., \& Dods, K. (2008). Cooking quality of faba bean after storage at high temperature and the role of lignins and other phenolics in bean hardening. LWT-Food Science and Technology, 41(7), 1260-1267.

National research council. (2006). Lablab.Lost crops of Africa: Volume II: Vegetables. Washington DC:
The National Academies Press. https://doi.org/10.17226/11763

Nazni, P., \& Devi, S. R. (2016). Effect of Processing on the Characteristics Changes in Barnyard and Foxtail Millet. J Food Process Technol, 7(3), 1-8. https://doi.org/10.4172/2157-7110.1000 566

Nwafor, F. I., Egonu, S. N., Nweze, N. O., \& Ohabuenyi, N. (2017). Effect of processing methods on the nutritional values and antinutritive factors of Adenanthera pavonina $\mathrm{L}$. (Fabaceae) seeds. African Journal of Biotechnology, 16(January), 106-112. https://doi.org/10.5897/AJB2016.15782

Nyamongo, D., Okwuosa, E., Kimani, S., Ngae, G., Mbure, G., Kimani, J., Otieno, Z. (2015). Plant Genetic Resources (PGR) policy and legal framework in the context of climate change in Kenya. Nairobi-Kenya.

Ojo, M. A., \& Ade-omowaye, B. I. (2015). Some Functional and Physical Properties of Selected Underutilised Hard-To-Cook Legumes in Nigeria. American Journal of Food Science and Nutrition 2015, 2(5), 73-81.

Okoth, J. K., Ochola, S., Gikonyo, N. K., \& Makokha, A. A. (2011). Optimization of the Period of Steeping and Germination for Amaranth Grain. Journal of Agriculture and Food Technology, 1(6), 101-105.

Oluwole, A., \& Olayinka, F. A. (2011). Effects of Dehulling on Functional and Sensory Properties of Flours from Black Beans (Phaseolus vulgaris). Food and Nutrition Sciences, 2, 344-349. https://doi.org/10.4236/ fns. 2011.24049

Osman, M. A. (2007). Changes in nutrient composition, tripsin inhibitor, phytate, tannins and protein digestibility of dolichos lablab [Lablab purpureus (L) Sweet] occurring during germination. Food Technology, 5(4), 294-299.

Padmashree, A., Semwal, A. D., Khan, M. A., Govindaraj, T., \& Sharma, G. K. (2016). Effect of infrared processing on functional, nutritional, antinutritional and rheological properties of mung bean (Phaseolus aereus) seeds. International Journal of Advanced Research, 4(1), 606-613.

Pious, S. T., \& Veerabahu, R. M. (2013). Assessment of nutritional and antinutritional potential of underutilized legumes of the genus Mucuna. 
Tropical and Subtropical Agroecosystems, 16, 155-169.

Prince ML, Van Scoyoc S, B. L. (1978). Critical evaluation of the vanillin reaction as an assay for tannin in sorghum grain. Agric. Food Chem, (26), 1214-1218.

Ramakrishna, V., Rani, P. J., \& Rao, P. R. (2006). AntiNutritional Factors During Germination in Indian Bean (Dolichos lablab L .) Seeds. World Journal of Dairy \& Food Sciences, 1(1), 0611.

Reddy, C. S., Andrapradesh, W., Kante, K., \& Reddy, C. S. (2013). Anti diabetic activity of Dolichos, lablab (seeds) in Streptozotocin- Nicotinamide induced diabetic rats. Journal for Drugs and Medicines, 5(April), 32-40.

Sánchez-Chino, X., Jiménez-Martínez, C., Dávila-Ortiz, G., Álvarez-González, I., \& Madrigal-Bujaidar, E. (2015). Nutrient and Nonnutrient Components of Legumes, and Its Chemopreventive Activity: A Review. Nutrition and Cancer, 67(3), 401-410. https://doi.org/10.1080/01635581.2015.100 4729

Shaahu, D. T., Carew, S. N., \& Ikurior, S. A. (2015). Effect Of Processing On Proximate, Energy, Anti- Nutritional Factor, Amino Acid And Mineral Composition of Lablab Seed. International Journal of Scientific \& Technology Research, 4(4). Retrieved from www.ijstr.org

Shaahu, D. T., Kaankuka, F. G., \& Okpanachi. (2015). Proximate, Amino Acid, Anti-Nutritional Factor And Mineral Composition Of Different Varieties Of Raw Lablab Purpureus Seeds. International Journal of Scientific \& Technology Research, 4(4). Retrieved from www.ijstr.org

Singhal, P., Kaushik, G., \& Mathur, P. (2014a). Antidiabetic Potential of Commonly Consumed Legumes: A Review Antidiabetic Potential of Commonly Consumed Legumes: A Review. Critical Reviews in Food Science and Nutrition, 54(5), 655-672. https://doi.org/ 10.1080/10408398.2011.604141

Singhal, P., Kaushik, G., \& Mathur, P. (2014b). Antidiabetic potential of commonly consumed legumes: a review. Critical Reviews in Food Science and Nutrition, 54(5), 655-72. https://doi.org/10.1080/10408398.2011.60414 1
Soetan, K. O., \& Oyewole, O. E. (2009). The need for adequate processing to reduce the antinutritional factors in plants used as human foods and animal feeds: A review. African Journal of Food Science, 3(9), 223-232. Retrieved http://www.academicjournals.org/AJFS

Sridhar, K. R., \& Seena, S. (2006). Nutritional and antinutritional significance of four unconventional legumes of the genus Canavalia - A comparative study. Food Chemistry, 267-288. https://doi.org/10.1016/j.foodchem.2005.07.04 9

Subagio, A. (2006). Characterization of hyacinth bean( Lablab purpureus ( $L$.) sweet ) seeds from Indonesia and their protein isolate. Food Chemistry, 95(1), 65-70. https://doi.org/ 10.1016/j.foodchem.2004.12.042

Thapliyal, P., Sehgal, S., \& Kawatra, A. (2014). In-vitro digestibility and antinutrients as affected by soaking, dehulling and pressure-cooking of chickpea (Cicer arietinum) varieties. Asian Journal of Dairy and Food Research, 33(2), 131. https://doi.org/10.5958/0976-0563.2014. 00589.2

Tharanathan, R. N., \& Mahadevamma, S. (2003). Grain legumes - A boon to human nutrition. Trends in Food Science and Technology, 14(12), 507-518. https://doi.org/10.1016/j.tifs.2003. 07.002

Vijayakumari, K., Siddhuraju, P., \& Janardhanan, K. (1997). Effect of domestic processing on the levels of certain antinutrients in Prosopis chilensis (Molina) Stunz. seeds. Food Chemistry, 59(3), 367-371. http://dx.doi.org/ 10.1016/S0308-8146(96)00249-X

Vohra, K., Dureja, H., \& Garg, V. (2015). An Insight of Pulses: From Food to Cancer Treatment. Phamacognosy \& Natural Products, 1(1), 1-7. https://doi.org/10.4172/jpnp.1000108

Wang, N., Hatcher, D. W., Tyler, R. T., Toews, R., \& Gawalko, E. J. (2010). Effect of cooking on the composition of beans (Phaseolus vulgaris $\mathrm{L}$.) and chickpeas ( Cicer arietinum L .) q. Food Research International, 43(2), 589-594. https://doi.org/10.1016/j.foodres.2009.07.012

WHO/FAO. (2002). Food energy - methods of analysis and conversion. FAO Food and Nutrition Paper, 93. https://doi.org/ISSN 0254-4725 